Biol. Stud. 2018: 12(3-4); 35-46 • DOI: https://doi.org/10.30970/sbi.1203.578

www.http://publications.Inu.edu.ua/journals/index.php/biology

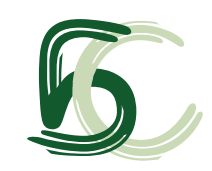

UDC 577.115:661.875

\title{
EFFECT OF CHROMIUM CITRATE ON LIPID COMPOSITION IN BLOOD PLASMA OF RATS WITH EXPERIMENTAL DIABETES
}

\author{
R. Iskra, O. Sushko*, A. Pylypets, O. Slivinska \\ Institute of Animal Biology, NAAS, 38, V. Stus St., Lviv 79034, Ukraine \\ ${ }^{*}$ Corresponding author: e-mail: sushko.ola@gmail.com
}

Iskra R., Sushko O., Pylypets A., Slivinska O. Effect of chromium citrate on lipid composition in blood plasma of rats with experimental diabetes. Studia Biologica, 2018: 12(3-4); 35-46 - DOI: https://doi.org/10.30970/sbi.1203.578

The results of studying changes of lipid composition in blood plasma of rats with alloxan-induced diabetes under the condition of consumption of chromium citrate in the concentration of 0.1 and $0.2 \mu \mathrm{g} / \mathrm{ml}$ of water are presented. The experiment was conducted on 32 laboratory rats. The rats were divided in four groups: K1 - control group, K2 - control group with diabetes, R1 and R2 - experimental groups. Pure water (without any additives) was given to the rats of groups $\mathrm{K} 1$ and $\mathrm{K} 2$. Water with chromium citrate in concentration of 0.1 and $0.2 \mu \mathrm{g} / \mathrm{ml}$ was given to the animals from groups R1 and R2 for one month. Experimental diabetes mellitus was induced in the animals of groups $\mathrm{K} 2$, $\mathrm{R} 1$, and R2 by the intraperitoneal injection of $5 \%$ solution of alloxan monohydrate in concentration of $150 \mathrm{mg} / \mathrm{kg}$ of body weight. Total lipids content and their classes were determined in animals' blood plasma.

It was found that an imbalance was present in the lipid profile and the phospholipid profile of animals with experimental diabetes mellitus. In particular, the content of total lipids and relative content of non-esterified cholesterol increased significantly, and there was a tendency of the content of triacylglycerols and unesterified fatty acids to be increased in the rats' blood with experimental diabetes mellitus of K2 group. There was a shift in spectrum of different fractions when the content of phospholipids decreased in blood of rats with experimental diabetes mellitus.

The content of total lipids, esterified and non-esterified cholesterol significantly decreased and the content of triacylglycerols and unesterified fatty acids was significantly lower in animals of the experimental groups R1 and R2, but the content of phospholipids increased in the same groups. Changes in content of certain classes of lipids in blood

(ㄷ 2018 R. Iskra et al.; Published by the Ivan Franko National University of Lviv on behalf of Біологічні Студії / Studia Biologica. This is an Open Access article distributed under the terms of the Creative Commons Attribution License (http://www.budapestopenaccessinitiative.org/ and Creative Commons Attribution 4.0 License), which permits unrestricted reuse, distribution, and reproduction in any medium, provided the original work is properly cited.

ISSN 1996-4536 (print) • ISSN 2311-0783 (on-line) • Біологічні Студії / Studia Biologica • 2018 • Том 12/№3-4 • С. 35-46 
of rats with alloxan diabetes affected by additives of citrate chromium are multidirectional and dose-dependent.

Keywords: rats, chromium citrate, blood, total lipids, phospholipids

\section{INTRODUCTION}

Chromium $(\mathrm{Cr})$ is an essential trace element in humans, and most species of animals, and it is a part of the oligopeptide of chromodulin which activates the action of insulin by promoting hormone binding with the receptors on cell surface [21]. Trivalent chromium is involved in the metabolism of living organisms since it regulates carbohydrate, protein, and lipid metabolism [5; 6; 9]. When it comes to insufficiency or excess, there are metabolic disorders that contribute to a development of hyperglycemia, obesity, atherosclerosis, peripheral neuropathy, growth retardation, impaired functioning of the higher nervous activity, lowered immune system, and decreased lifespan $[1 ; 10]$. Several authors $[7 ; 10 ; 17 ; 19]$ have demonstrated that $\mathrm{Cr}$ (III) is useful for treating insulin resistance and diabetes mellitus. It should be noted that in recent years there is an increase in number of people with diabetes and overweight.

Chromium is involved in normalization of lipid metabolism in the body. Some researchers have demonstrated the ability of chromium picolinate to lower cholesterol and triacylglycerol levels in blood plasma, suppress a secretion of inflammatory cytokines in insulin-dependent patients with type II diabetes [6]. However, in other studies, it was found that the addition of this compound to the diet of healthy people did not cause changes in the level of lipids in their blood [22]. Chromium stimulates lipogenesis and inhibits lipolysis that results in a decrease of concentration of un-esterified fatty acids in blood against the background of increased sensitivity of cells to insulin [13].

Polyunsaturated fatty acids occupy a central position in the non-limiting chain of antioxidant defense in the body. At the same time, peroxide oxidation of polyunsaturated fatty acids in low-density lipoproteins plays an important role in pathogenesis of atherogenesis. Intermediate metabolites of biohydrogenation of the linoleic and linolenic acids - diene conjugates - are biologically active compounds that have a regulatory effect and prevent oncological and cardiovascular diseases in humans [11].

By using the in vitro studies of the influence of $\mathrm{Cr}$ (III) on lipogenesis in turkeys' liver cells it was found that the conversion of glucose to acetyl-CoA has increased, while the conversion of acetyl-CoA to fatty acids has not changed [20]. Based on these studies, it can be assumed that $\mathrm{Cr}$ increased cellular glucose uptake only. However, other authors have experimentally proved the influence of chromium propionate on lipogenesis in adipose tissue of dairy cows [18]. Evidently, chromium enhances insulin-stimulated glucose transport and this leads to an increase in the activity of lipoprotein lipase and, thus, facilitates the intake of fatty acids in the cells of adipose and muscle tissue [8].

The purpose of our experiments was to find out the influence of various doses of chromium citrate on the lipid profile in blood plasma of rats with experimental diabetes.

ISSN 1996-4536 (print) • ISSN 2311-0783 (on-line) • Біологічні Студії / Studia Biologica • 2018 • Том 12/№3-4 • С. 35-46 


\section{MATERIALS AND METHODS}

Animals. In the experiment, laboratory rats weighing 100-120 g were used. The rats were maintained under standard vivarium conditions with a feeding and drinking regime at the level recommended by the standards for keeping laboratory animals. The rats were divided into four groups. Animals of control groups - K1 and K2 - received pure water without additives, and the animals of the experimental groups - R1 and R2 - were consuming chromium citrate for one month as an addition to drinking water in doses of 0.1 and $0.2 \mu \mathrm{g} / \mathrm{ml}$ of water in order to induce experimental diabetes mellitus (EDM), four weeks after the commencement of the experiment in rats of $\mathrm{K} 2$, R1, and R2 groups. Diabetes mellitus was induced by intraperitoneal administration of a $5 \%$ solution of alloxan monohydrate in concentration of $150 \mathrm{mg} / \mathrm{kg}$ of body weight after a 24-hour fasting period. In order to detect hyperglycemia, we collected the blood from the tail vein and measured glucose level in the collected blood using a portable glucose meter ("Gamma-M", UK). Dynamics of changes in glucose level was carried out immediately before the start of the experiment, on the $1^{\text {st }}, 15^{\text {th }}$, and $30^{\text {th }}$ days of the experiment, and was continued after the injection of alloxan on the $32^{\text {nd }}, 36^{\text {th }}$, and $40^{\text {th }}$ days of studies. Glucose level in rat blood $>11.1 \mathrm{mmol} / \mathrm{L}$ was accepted as a successful induction of diabetes mellitus. Normal healthy rats were injected with $0.9 \%$ of physiological saline.

After the completion of the experiment, animals were decapitated under mild chloroform anesthesia, without the violations of the standards of bioethycal treatment of laboratory animals and taking into account generally accepted bioethical norms and in accordance with the international regulations concerning the conduction of the experimental works. The experiment was conducted according to the provisions of the "European Convention for the Protection of Vertebrate Animals used for Experiments and Other Scientific Purposes", European Treaty Series - No. 123 (Strasbourg, 1985) and "General Ethical Principles of Animal Experiments" adopted by the First National Congress on Bioethics (Kyiv, 2001). Protocol of the meeting of the Bioethics Committee of the Institute of Animal Biology No. 76 was dated by November 6, 2018.

Blood plasma of rats was obtained by centrifugation of heparinized blood at $300 \mathrm{rpm}$ for $10 \mathrm{~min}$.

Obtaining of common lipids. Blood plasma $\left(1 \mathrm{~cm}^{3}\right)$ was extracted with chloroform-methanol mixture in the ratio 2:1 (v/v) according to Folch method [4]. To clean the lipid extract, a $0.74 \mathrm{M}$ of $\mathrm{KCl}$ solution was added. The total amount of lipids was determined by weighing dry using a residue gravimetric method [12].

Separation of lipids into classes. The separation of lipids into classes was carried out by thin layer chromatography (TLC) on silica gel (silica gel L 5/40 $\mu$, LSL 5/40 $\mu$, Chemapol, Slovakia), as a mobile phase hexane-diethyl ether-acetic acid in ratio 70:30:1 (v/v/v) was used [12]. Plates were obtained using the vapors of crystalline iodine. Identification of individual lipids was carried out by Rf values [14]. The developed plates were scanned (HP Scanjet G2710, China). Quantitative analysis and counting of the contents of the lipid classes were performed by computer processing of foregrams using the TotalLab TL120 software (Nonlinear Dynamics Limited, UK) and expressed as a percentage of the total pool.

ISSN 1996-4536 (print) • ISSN 2311-0783 (on-line) • Біологічні Студії / Studia Biologica • 2018 • Том 12/№3-4 • С. 35-46 
The content of non-esterified cholesterol (NEC) and esterified cholesterol (EC), phospholipids (PL), monoglycerols and diacylglycerols (MDAG), triacylglycerols (TAG), and non-esterified fatty acids (NEFA) were identified in rats' blood plasma.

Separation of phospholipids. For separation of the phospholipids by TLC method on a silica gel, solvent system of chloroform-methanol-water in ratio 65:25:4 (v/v/v) was used [14]. Crystalline iodine vapors were used as a developer. The identification of individual phospholipids was carried out by Rf values [14]. The obtained plates were scanned. Quantitative analysis and counting of the individual lipids content were performed by computer processing of the foregrams using the TotalLab TL120 software (Nonlinear Dynamics Limited, UK) and expressed as a percentage of the total pool.

Blood plasma of rats was examined to identify a content of the phosphatidic acid $(\mathrm{PA})$, cardiolipin $(\mathrm{CL})$, phosphatidylethanolamine (PE), phosphatidylinositol (PI), phosphatidylcholine (PC), phosphatidylserine (PS), sphingomyelin (SM) and lysophosphatidylcholine (LPC) in rats' blood plasma.

Statistical analysis. The obtained digital data were processed statistically using the Microsoft Excel 2016 package. We calculated the mean and standard error of the mean $(M \pm m)$. To determine probable differences between the statistical groups, the Student's criterion was used.

\section{RESULTS AND DISCUSSION}

Alloxan is used to induce experimental diabetes by a selective damage of the ultrastructure of the $\beta$-cells of the Langerhans of the pancreas producing insulin. Changes in the concentration of insulin in blood plasma lead to changes in blood glucose levels. Glucose level fluctuated during the experiment in a range of 5.69-6.94 mmol/L in animals of control groups. In rats of the $\mathrm{K} 2$ group with diabetes, that rate varied: $5.88 \mathrm{mmol} / \mathrm{L}$ at the beginning of the trial, $16.25 \mathrm{mmol} / \mathrm{L}$ on the first day, and $22.93 \mathrm{mmol} / \mathrm{L}$ on the $10^{\text {th }}$ day after the injection of alloxan, which confirms the emergence of significant hyperglycemia. Introduction of a solution of chromium citrate reduces glucose level in blood of animals with DM. The glucose level in the R1 group was $6.05 \mathrm{mmol} / \mathrm{L}$ at the beginning of the trial, $15.73 \mathrm{mmol} / \mathrm{L}$ on the first day after the injection of alloxan, and $16.91 \mathrm{mmol} / \mathrm{L}$ on the 10th day after drug administration. This index varied in the R2 group: from $6.61 \mathrm{mmol} / \mathrm{L}$ at the beginning of the trial, to $15.83 \mathrm{mmol} / \mathrm{L}$ on the first day after the administration of alloxan, and to $18.64 \mathrm{mmol} / \mathrm{L}$ on the $10^{\text {th }}$ day after the administration of the drug. The obtained results indicate that citrate may alter blood glucose level during diabetes mellitus.

Body mass was measured at baseline and throughout the study. All animals of the experimental groups were characterized by slight difference in their body weight at the beginning of the experiment. The body weight of the experimental animals was decreased by $26.6 \%(P<0.001)$ in the $K 2$ diabetic group relative to the control group $K 1$ on the $40^{\text {th }}$ day. The body weight of animals decreased significantly in the experimental groups R1 and R2 - by 17.3 and $19.8 \%(P<0.001)$ comparing to the control group K1. The body mass index increased significantly under the effect of chromium citrate in the experimental groups $R 1$ and $R 2$ - by $12.7 \%(P<0.001)$ and $9.6 \%(P<0.01)$ relative to the $\mathrm{K} 2$ diabetic group.

ISSN 1996-4536 (print) • ISSN 2311-0783 (on-line) • Біологічні Студії / Studia Biologica • 2018 • Том 12/№3-4 • С. 35-46 
It was found that the content of total lipids was significantly increased in rats' blood plasma of the K2 group - by $25.65 \%(P<0.05)$ relative to the animals of the K1 group (Table 1). An increase in the content of total lipids in animals' blood plasma with experimental diabetes can be explained by the mobilization of fats from the depot (the lipomobilization syndrome).

The content of total lipids was reduced under the influence of chromium citrate in the concentrations of 0.1 and $0.2 \mu \mathrm{g} / \mathrm{ml}$ of water in animals' blood plasma: decrease in animals of $\mathrm{R} 1$ group by $18.72 \%(\mathrm{P}<0.05)$ comparing to animals of $\mathrm{K} 2$ group.

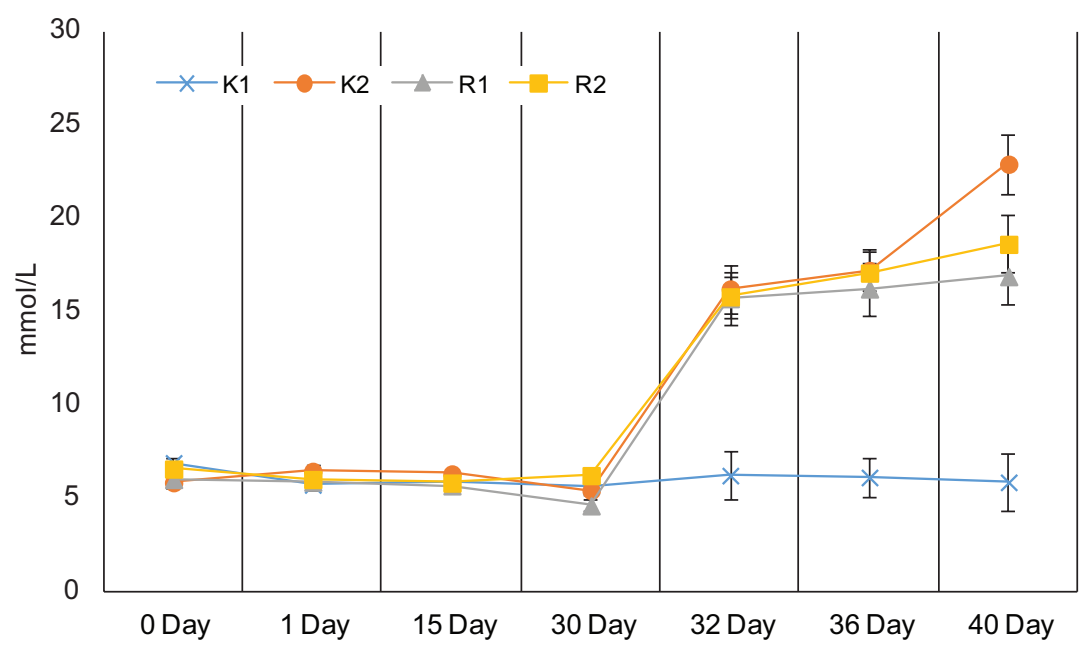

Dynamics of blood glucose in rats of control group, diabetic group, and under the effect of chromium citrate in concentration of 0.1 and $0.2 \mu \mathrm{g} / \mathrm{ml}$ of water $(\mathrm{M} \pm \mathrm{m}), \mathrm{n}=8$

Динаміка глюкози у крові щурів контрольної групи, діабетичної групи та за дії цитрату хрому в концентрації 0,1 і 0,2 мкг/мл води $(\mathrm{M} \pm \mathrm{m}), \mathrm{n}=8$

Significant changes in content of triacylglycerols in animals' blood plasma of the control and experimental groups were not identified during this study. However, content of triacylglycerols was increased in animals' blood of the K2 and R1 groups compared to animals of the $\mathrm{K} 1$ group. This content was decreased in animals of the R2 group relative to the $\mathrm{K} 2$ group animals.

An increase in content of triacylglycerols is due to their biosynthesis from L- $\alpha$ glycerol phosphate produced during glucose metabolism. It is known that the intensity of triacylglycerols synthesis changes under the influence of insulin [2]. The increase of TAG amount in the animals' blood plasma of the K2 and R1 groups may be a compensatory response to a decrease in the content of PL in animals of the same group.

The content of the non-esterified fatty acids was slightly increased in animals' blood of the K2 group relative to the animals of the K1 group, which might be caused by a increased lipolysis that occurs due to insulin deficiency. Increase of the concentration of cortisol and catecholamines also enhances this process. NEFA is released and transported to the liver where a reduced insulin level and elevated glucagon level lead to an increase in the proportion of fatty acids that are a subject to $\beta$-oxidation.

ISSN 1996-4536 (print) • ISSN 2311-0783 (on-line) • Біологічні Студії / Studia Biologica • 2018 • Том 12/№3-4 • С. 35-46 
Table 1. Lipid profile in blood plasma of rats with experimental diabetes under the effect of chromium citrate in the amount of 0.1 (R1) and 0.2 (R2) $\mu \mathrm{g} / \mathrm{ml}$ of water $(\mathrm{M} \pm \mathrm{m}), \mathrm{n}=\mathbf{8}$

Таблиця 1. Ліпідний профіль плазми крові щурів з експериментальним діабетом за дії

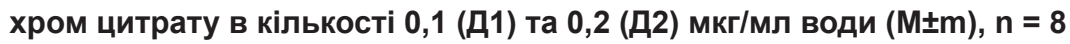

\begin{tabular}{l|c|c|c|c|}
\hline \multicolumn{1}{|c}{ Indicators } & \multicolumn{4}{c}{ Animals groups } \\
\cline { 2 - 5 } & $\mathrm{K} 1$ & $\mathrm{~K} 2$ & $\mathrm{R} 1$ & $\mathrm{R} 2$ \\
\hline Total lipids, g/L & $6.12 \pm 0.41$ & $7.69 \pm 0.41^{*}$ & $6.25 \pm 0.32^{\#}$ & $6.80 \pm 0.21$ \\
\hline $\begin{array}{l}\text { Triacylglycerols, \% } \\
\text { Monoacylglycerols and }\end{array}$ & $16.85 \pm 1.01$ & $17.20 \pm 0.68$ & $17.43 \pm 1.17$ & $16.06 \pm 0.25$ \\
\hline $\begin{array}{l}\text { diacylglycerols, \% } \\
\text { Non-esterified fatty acids, \% }\end{array}$ & $10.71 \pm 0.92$ & $11.86 \pm 0.36$ & $12.55 \pm 0.79$ & $12.64 \pm 0.27$ \\
\hline Esterified cholesterol, \% & $20.55 \pm 0.66$ & $20.03 \pm 0.82$ & $18.65 \pm 0.45^{*}$ & $17.78 \pm 0.34^{* * \#}$ \\
\hline Non-esterified cholesterol, \% & $7.06 \pm 0.28$ & $9.12 \pm 0.16^{* * *}$ & $9.16 \pm 0.11^{* * *}$ & $8.56 \pm 0.12^{* * * \#}$ \\
\hline Phospholipids, \% & $30.28 \pm 0.86$ & $26.37 \pm 0.40^{* *}$ & $27.30 \pm 0.32^{* *}$ & $30.38 \pm 1.29^{\#}$ \\
\hline
\end{tabular}

Comments: Here and onward, the probability of indices of K2, R1, and R2 groups relative to the K1 group: ${ }^{*}-\mathrm{P}<0.05$; ${ }^{* *}-\mathrm{P}<0.01$; ** $-\mathrm{P}<0.001$. The probability of indices of $\mathrm{R} 1$ and $\mathrm{R} 2$ groups relative to the K2 group: \# $-\mathrm{P}<0.05$; ${ }^{\#}-\mathrm{P}<0.01$; ${ }^{\# \#}-\mathrm{P}<0.001$

Примітки: У цій та наступній таблицях вірогідність показників К2, Д1 і Д2 груп стосовно К1 групи: * $-\mathrm{P}<0,05 ;{ }^{*}-\mathrm{P}<0,01$; ${ }^{* *}-\mathrm{P}<0,001$. Вірогідність показників Д1 і Д2 груп стосовно К2 групи: \# $-\mathrm{P}<0,05 ;{ }^{\#}-\mathrm{P}<0,01 ;{ }^{\# \#}-\mathrm{P}<0,001$

It has been identified that the content of esterified cholesterol was decreased by $9.25 \%(P<0.05)$ and $13.48 \%(P<0.01)$ in rats' blood plasma of the R1 and R2 groups respectively, relative to the content in animals of the $\mathrm{K} 1$ group, and was decreased by 6.89 and $11.23 \%(P<0.05)$ relative to the content in the animals with experimental diabetes of the K2 group. Obviously, the esterified cholesterol which is usually found in cells is hydrolyzed under the influence of chromium citrate.

It is known that phospholipids and non-esterified cholesterol influence the permeability of membranes, provide their ultrastructure and functional activity, intensify the work of a lot of membrane-bound enzymes and passive transport systems, as well as a density of the bilayer membrane. In particular, phospholipids determine the plastic and fluid properties of cell membranes and organoids, while cholesterol causes stiffness and stability of the membrane [15]. A probability of occurrence of atherosclerosis and coronary heart disease and the intensity of synthesis in the organs and glands of bile acids of 25-OH-vitamin D3, sex hormones, and hormones of the adrenal glands depend on the level of cholesterol in blood [11].

Content of the non-esterified cholesterol was significantly increased in animals' blood of the K2 group by $29.18 \%(P<0.001)$, of the R1 group $-29.74 \%(P<0.001)$, and of the R2 group by $21.25 \%(P<0.001)$ compared to animals of the K1 group. An increase in content of the non-esterified cholesterol of animals is possible when a use of the acetyl-CoA in Krebs cycle (citrate synthetical reaction) is slowed down due to

ISSN 1996-4536 (print) • ISSN 2311-0783 (on-line) • Біологічні Студії / Studia Biologica • 2018 • Том 12/№3-4 • С. 35-46 
a deficiency of oxaloacetate, which, under the conditions of the EDM, is used for gluconeogenesis. Synthesis of fatty acids with acetyl-CoA is blocked due to the inhibition by an excess of fatty acids of the initial reaction of the process - the formation of malonylCoA (acetyl-CoA carboxylase reaction). The deficiency of NADPH also causes the inhibition of synthesis of fatty acids. Thus, only the condensation of acetyl-CoA to $\beta$-hydroxy$\beta$-methylglutaryl-CoA remains unblocked with further formation of ketone bodies and cholesterol [16].

The content of non-esterified cholesterol was decreased by $6.14 \%(P<0.05)$ in the animals' blood of the R2 group relative to the animals of the K2 group. This suggests changes in the processes of esterification and hydrolysis of cholesterol in organism under the influence of chromium citrate in $0.2 \mu \mathrm{g} / \mathrm{ml}$ dose. A decrease in the amount of nonesterified cholesterol in animals' blood plasma, apparently, is associated with an increase in the intensity of its transformation in liver into bile acids and $25-\mathrm{OH}$-vitamin D3, in the adrenal glands - in corticosteroids, and in the sex glands - in androgens.

Content of the phospholipids was decreased by $12.91 \%(P<0.01)$ in animals' blood of the K2 group and decreased by $9.84 \%(P<0.01)$ in the R1 group compared to the $\mathrm{K} 1$ group. A decrease in the phospholipids content in animals can be explained by an increased activation of their hydrolysis, intensification of lipid peroxidation processes (LPO), that affects an integrity of the lipid bilayer of cell membranes and decreases the activity of phospholipid-dependent enzymatic systems. It is known that enzymatic activity, hormonal response, and the permeability of membranes depend on physical and chemical properties of the phospholipid bilayer of plasma membrane. Therefore, due to diabetes, there is a disproportion in the phospholipid composition of the cells, that affects membrane density, permeability, and the activity of enzymes such as protein kinase C, PI3-kinase, and Akt-kinase (RAC-alpha serine/threonineprotein kinase).

The content of phospholipids was significantly increased in animals of the R2 group by $15.21 \%(P<0.05)$ compared to the animals of the K2 group (Table 1). An increase in the content of phospholipids in animals' blood indicates the intensification of their synthesis, and, accordingly, their content in the body tissues might be a kind of protection of body cells from the penetration of toxicants through their membrane by increasing the density of their membranes. Additionally, phospholipids activate enzymes that leave cholesterol ethers and partially purify the intima of blood vessels also affect the activity of the lipoprotein lipase.

There was a shift in spectrum of different fractions of phospholipids. Changes in the composition of phospholipids in blood plasma of rats with EDM might occur compensatory in a response to an increase in total lipids of the organism. Thus, the content of phosphatidylcholine was increased in animals of the K2 group by $13.24 \%(P<0.05)$ compared to animals of the $\mathrm{K} 1$ group, that occurs as a result of an increased choline kinase activity, and as a consequence, the conversion of choline to choline phosphate is intensified.

In animals of experimental groups R1 and R2, the content of phosphatidylcholine was decreased by $13.92 \%(P<0.001)$ and $8.05 \%(P<0.05)$ compared to the animals of the K1 group. The content of phosphatidylcholine was decreased by $23.99 \%$ $(P<0.001)$ and $18.80 \%(P<0.001)$ compared to the animals of the K2 group. This may occur due to an indirect inhibition of the activity of choline kinase by chromium citrate.

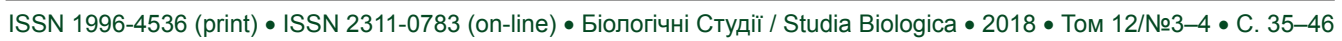


The content of phosphatidylethanolamine was significantly reduced in the animals of the K2 group by $20.04 \%(P<0,001)$ relative to the animals of the K1 group. We observed a significant increase in the content of PE in the animals of the R1 and R2 groups by $23.89 \%(P<0.001)$ and $33.13 \%(P<0.01)$ in relation to the animals of the $\mathrm{K} 2$ group.

It is possible that a normalization of the content of PC and PE under the action of chromium citrate contributes to the restoration of the insulin receptor. It is known that, the metabolism of these phospholipids is closely related to the transmembrane signals in the cell and the activation of protein kinase $\mathrm{C}$. In addition, it was found that the content of the phosphatidic acid was increased in animals of the R1 group by $18.02 \%(P<0.05)$ compared to the animals of the K1 group and increased by $17.17 \%(P<0.05)$ compared to the animals of the K2 group. Changes in the content of PA in the animals' blood plasma of other groups were out of statistical control (Table 2).

It was observed that the content of cardiolipin was decreased by $28.34 \%(P<0.001)$ and by $11.37 \%(P<0.05)$ in animals with experimentally induced diabetes of the K2 group and in animals of the R2 group, respectively. These results were compared to the data obtained in animals of the $\mathrm{K} 1$ group.

Introduction of chromium citrate to animals contributed to an increase in the content of cardiolipin in animals of the R1 and R2 groups by $30.52 \%(P<0.01)$ and $23.69 \%$ $(P<0.01)$ relative to animals of the $K 2$ group. This might be due to a decrease in the level of oxidative stress under the action of chromium citrate which is indirectly the detection of its antioxidant properties [10].

Table 2. Phospholipids in blood plasma of rats with experimental diabetes under the effect of chromium citrate in the amounts of 0.1 (R1) and 0.2 (R2) $\mu \mathrm{g} / \mathrm{ml}$ of water $(\mathrm{M} \pm \mathrm{m}), \mathrm{n}=\mathbf{8}$

Таблиця 2. Фосфоліпіди плазми крові щурів з експериментальним діабетом за дії

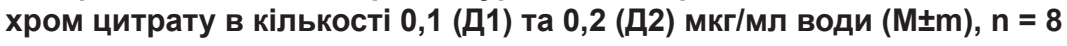

\begin{tabular}{|c|c|c|c|c|}
\hline \multirow{2}{*}{ Phospholipids } & \multicolumn{4}{|c|}{ Animals groups } \\
\hline & K1 & K2 & R1 & $\mathrm{R} 2$ \\
\hline Phosphatidic acids, \% & $10.93 \pm 0.39$ & $11.01 \pm 0.26$ & $12.90 \pm 0.68^{\star \#}$ & $11.73 \pm 0.59$ \\
\hline Cardiolipin, \% & $6.95 \pm 0.21$ & $4.98 \pm 0.30^{* * *}$ & $6.50 \pm 0.31^{\# \#}$ & $6.16 \pm 0.18^{\star \# \#}$ \\
\hline Phosphatidylethanolamine, \% & $19.21 \pm 0.42$ & $15.36 \pm 0.35^{* * *}$ & $19.03 \pm 0.52^{\# \#}$ & $20.45 \pm 1.05^{\# \# \#}$ \\
\hline Phosphatidylinositol, \% & $9.04 \pm 0.42$ & $8.96 \pm 0.34$ & $8.36 \pm 0.41$ & $7.38 \pm 0.36^{* * \# \#}$ \\
\hline Phosphatidylcholine, \% & $35.41 \pm 0.72$ & $40.10 \pm 1.60^{*}$ & $30.48 \pm 0.93^{\star * \star \ldots \#}$ & 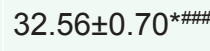 \\
\hline Phosphatidylserine, \% & $5.63 \pm 0.49$ & $7.79 \pm 0.22^{* *}$ & $6.93 \pm 0.15^{\star \# \#}$ & $6.86 \pm 0.19^{\star \# \#}$ \\
\hline Sphingomyelin, \% & $5.20 \pm 0.37$ & $5.86 \pm 0.27$ & $7.66 \pm 0.56^{\star * \#}$ & $6.78 \pm 0.24^{* * \#}$ \\
\hline Lysophosphatidylcholine, \% & $7.64 \pm 0.35$ & $5.94 \pm 0.25^{\star *}$ & $8.15 \pm 0.49^{\# \prime}$ & $8.09 \pm 0.60^{\# \#}$ \\
\hline
\end{tabular}

Content of the phosphatidylinositol was significantly decreased in animals of the R2 group by $18.36 \%(\mathrm{P}<0.01)$ compared to animals of the $\mathrm{K} 1$ group and decreased by

ISSN 1996-4536 (print) • ISSN 2311-0783 (on-line) • Біологічні Студії / Studia Biologica • 2018 • Том 12/№3-4 • С. 35-46 
$17.63 \%(\mathrm{P}<0.01)$ compared to animals of the $\mathrm{K} 2$ group. Changes in the content of $\mathrm{PI}$ in the blood plasma in animals of other groups were unlikely.

An increase in content of the phosphatidylserine was detected in animals of the $\mathrm{K} 2$, R1, and R2 groups by $38.36 \%(P<0.01), 23.09 \%(P<0.05)$ and $21.85 \%(P<0.05)$ respectively, compared to animals of the $\mathrm{K} 1$ group.

A decrease in the content of PS was identified in animals of the experimental groups $\mathrm{R} 1$ and $\mathrm{R} 2$ by $11.04 \%(\mathrm{P}<0.01)$ and $11.93 \%(\mathrm{P}<0.01)$ respectively, compared to animals of the $\mathrm{K} 2$ group. It is possible due to a decrease in activation of the protein kinase $\mathrm{C}$ which interacts with the PS via the $\mathrm{C} 2$ domain. The obtained data of reducing the level of PS and increasing the content of PE in animals' blood plasma of experimental groups may indicate the activation of PE synthesis through the decarboxylation of the phosphatidylserine with an involvement of the phosphatidyl decarboxylase in liver.

Content of the sphingomyelin was increased in animals of the R1 and R2 groups by $47.31 \%(P<0.01)$ and $30.38 \%(P<0.01)$ respectively, compared to animals of the K1 group. The content of SM was also increased by $30.72 \%(P<0.05)$ and $15.70 \%$ $(P<0.05)$ in these groups compared to the animals of group $K 2$. It is known that an increase or decrease in the content of SM causes changes in physical and chemical properties of plasma membranes, ligand-receptor interactions, and conducting signals. An increase in the content of SM in blood plasma of experimental groups of rats can be explained by activation of the reaction of synthesis of SM with PA and activation of the Akt-kinase.

The content of lysophosphatidylcholine was significantly reduced in animals of the K2 group, respectively, by $22.25 \%(P<0.01)$ compared to animals of the K1 group. Reducing the content of LPC in animals' blood plasma may indicate a correlation between the processes associated with a formation of LPC and the development of metabolic disorders.

The content of LPC was significantly increased in animals of the R1 and R2 groups by $37.20 \%(P<0.01)$ and $36.19 \%(P<0.01)$ respectively, compared to animals with experimental diabetes of the K2 group. Introduction of chromium citrate to rats with experimental diabetes leads to an increase in content of LPC in blood plasma of animals of experimental groups to its level in animals of the control group K1. Perhaps, this is due to modulation of phospholipase A2, that is indicated by a decrease in the PC. It is known that normalization of the phospholipid lysoforms and their relationship with phosphatidylethanolamine contributes to a restoration of the activity of membrane-bound proteins and structure of plasma membrane.

Although the mechanism of action of $\mathrm{Cr}$ (III) on lipid metabolism occurs due to activation of the calmodulin-dependent protein kinase $\mathrm{V}$, which inhibits an expression of the specific protein - sterol regulatory element-binding protein 1 [3]. This protein belongs to lipogenic transcription factors which are directly involved in the induction of more than 30 genes that determine synthesis of cholesterol, fatty acids, triacylglycerols and phospholipids, as well as nicotinamide-adenine and dinucleotide phosphates, necessary for synthesis of these molecules.

\section{CONCLUSIONS}

Thus, an imbalance in the lipid and phospholipid profiles of blood plasma has been detected in the organisms of animals with experimental alloxan diabetes. Changes in the

ISSN 1996-4536 (print) • ISSN 2311-0783 (on-line) • Біологічні Студії / Studia Biologica • 2018 • Том 12/№3-4 • С. 35-46 
content of certain classes of lipids in rats' blood with alloxan diabetes influenced by citrate chromium additives are multidirectional and dose-dependent. Normalization of the level of lipid metabolism in rats' blood under the conditions of diabetes mellitus has been achieved by adding chromium citrate in the doses of $0.1-0.2 \mu \mathrm{g} / \mathrm{ml}$ of water.

1. Cefalu W.T., Hu F.B. Role of chromium in human health and in diabetes. Diabetes Care, 2004; 27(11): 2741-2751.

[DOI: https://doi.org/10.2337/diacare.27.11.2741]

2. Czech M.P., Tencerova M., Pedersen D.J., Aouadi M. Insulin signalling mechanisms for triacylglycerol storage. Diabetologia, 2013; 56(5): 949-964.

[DOI: https://doi.org/10.1007/s00125-013-2869-1]

3. Espenshade P.J. SREBPs: sterol-regulated transcription factors. Journal of Cell Science, 2006; 119: 973-976.

[DOI: https://doi.org/10.1242/jcs02866]

4. Folch J., Lees M., Stanley G. A simple method for the isolation and purification of total lipids from animal tissues. The Journal of Biological Chemistry, 1957; 226(1): 497-509.

5. Ganguly R., Sahu S., Ohanyan V., Haney R., Chavez R., Shah S., Yalamanchili S., Raman P. Oral chromium picolinate impedes hyperglycemia-induced atherosclerosis and inhibits proatherogenic protein TSP-1 expression in STZ-induced type 1 diabetic ApoE-/- mice. Scientific Reports, 2017;7: 45279.

[DOI: https://doi.org/10.1038/srep45279]

6. Ganguly R., Wen A.M., Myer A.B., Czech T., Sahu S., Steinmetz N.F., Raman P. Anti-atherogenic effect of trivalent chromium-loaded CPMV nanoparticles in human aortic smooth muscle cells under hyperglycemic conditions in vitro. Nanoscale, 2016; 8(12): 6542-6554. [DOI: https://doi:org/10.1039/C6NR00398B]

7. Hua Y., Clark S., Ren J., Sreejayan N. Molecular mechanisms of chromium in alleviating insulin resistance. The Journal of Nutritional Biochemistry, 2012; 23(4): 313-319. [DOI: https://doi.org/10.1016/j.jnutbio.2011.11.001]

8. Iskra R.Ja. The content of fatty acids in muscle and fatty tissues of pigs by the action of chromium chloride. Scientific Herald of Uzhgorod University. Biology, 2012; (32): 168-171. (In Ukrainian).

9. Iskra R.Ja. The peculiarities of operation of glutathione component of antioxidant protection and lipid metabolism in pregnant rat females under the action of chromium citrate. Studia Biologica, 2013; 7(1): 71-80. [DOI: https://doi.org/10.30970/sbi.0701.276]

10. Iskra R.Ja., Vlizlo V.V., Fedoruk R.S., Antonyak H.L. Chromium in animal nutrition. K.: Agrarian science, 2014. 312 p. (In Ukrainian).

11. Jenkins T.C., McGuire M.A. Major advances in nutrition: impact on milk composition. Journal of Dairy Science, 2006; 89 (4): 1302-1310. [DOI: https://doi.org/10.3168/jds.S0022-0302(06)72198-1]

12. Kates M. Techniques of lipidology. Amsterdam: Elsevier, 1986. 451 p.

13. Kegley E.B., Galloway D.L., Fakier T.M. Effect of dietary chromium-L-methionine on glucose metabolism of beef steers. Journal of Animal Science, 2000; 78(12): 3177-3183. [DOI: https://doi.org/10.2527/2000.78123177x]

14. Kondrakhin I.P., Kurilov N.V., Malakhov A.G. Clinical laboratory diagnostics in veterinary science. M.: Agropromizdat, 1985. 287 p. (In Russian).

15. Kozachok M.M., Osodlo G.V., Kucz T.V. The role and place of essential phospholipids in the treatment of chronic diffuse liver diseases. Suchasna gastroenterologiya. 2006; 4(30): 95-101. (In Ukrainian).

ISSN 1996-4536 (print) • ISSN 2311-0783 (on-line) • Біологічні Студії / Studia Biologica • 2018 • Том 12/№3-4 • С. 35-46 
16. Kuzyshyn O.V., Kovalishin N.V, Almashina H.V. Biochemistry of diabetes: 1. Theoretical part (review). Medical chemistry. 2010; 2: 74-115. (In Ukrainian).

17. Martin J., Wang Z.Q., Zhang X.H., Wachtel D., Volaufova J., Matthews D.E., Cefalu W.T. Chromium picolinate supplementation attenuates body weight gain and increases insulin sensitivity in subjects with type 2 diabetes. Diabetes Care, 2006; 29(8): 1826-1832. [DOI: https://doi.org/10.2337/dc06-0254]

18. McNamara J.P., Valdez F. Adipose Tissue Metabolism and Production Responses to Calcium Propionate and Chromium Propionate. Journal of Dairy Science, 2005, 88: 2498-2507. [DOI:https://doi.org/10.3168/jds.S0022-0302(05)72927-1]

19. Refaie F.M., Esmat A.Y., Mohamed A.F., Aboul Nour W.H. Effect of chromium supplementation on the diabetes induced-oxidative stress in liver and brain of adult rats. Biometals, 2009; 22(6): 1075-1087.

[DOI: https://doi.org/10.1007/s10534-009-9258-8]

20. Steele N.C., Rosebrough R.W. Effect of trivalent chromium on hepatic lipogenesis by the turkey poult. Poultry Science, 1981; 60(3): 617-622.

[DOI: https://doi.org/10.3382/ps.0600617]

21. Sundaram B., Singhal K., Sandhir R. Ameliorating effect of chromium administration on hepatic glucose metabolism in streptozotocininduced experimental diabetes. Biofactors, 2012; 38(1): 59-68.

[DOI:https://doi.org/10.1002/biof.194]

22. Wilson B.E., Gondy A. Effects of chromium supplementation on fasting insulin levels and lipid parameters in healthy, non-obese young subjects. Diabetes Research and Clinical Practice, 1995; 28(3): 179-184.

[DOI: https://doi.org/10.1016/0168-8227(95)01097-W]

\title{
ЛІПІДНИЙ ПРОФІЛЬ ПЛАЗМИ КРОВІ ЩУРІВ З ЕКСПЕРИМЕНТАЛЬНИМ ДІАБЕТОМ ЗА ДІЇ РІЗНИХ ДОЗ ХРОМ ЦИТРАТУ
}

\author{
Р. Я. Іскра, О. О. Сушко*, А. З. Пилипець, О. М. Слівінська \\ Інститут біології тварин, НААН, вул. В. Стуса, 38, Львів 79034, Україна \\ *Кореспондуючий автор: e-mail: sushko.ola@gmail.com
}

У статті представлено зміни ліпідного профілю плазми крові щурів з алоксановим цукровим діабетом за дії хром цитрату в дозах 0,1 і 0,2 мкг/мл води. У дослідженнях використані лабораторні щури, яких розділили на чотири групи. Тварини контрольних груп - К1 і К2 споживали питну воду без добавок, а тварини дослідних груп - Д1 і Д2 протягом місяця з питною водою споживали хром цитрат у дозах 0,1 та 0,2 мкг/мл води. Експериментальний цукровий діабет (ЦД $)$ викликали у щурів груп К2, Д1 і Д2 способом внутрішньоочеревинного введення 5\% розчину алоксан моногідрату в кількості 150 мг/кг маси тіла. У плазмі крові тварин визначали вміст загальних ліпідів і їхніх класів.

Унаслідок досліджень було встановлено, що у тварин з ЦД з'явився дисбаланс у ліпідному та фросфоліпідному профрілі плазми крові. Зокрема, у крові щурів з ЦД групи К2 вірогідно зростав вміст загальних ліпідів і відносний вміст неетерифікованого холестеролу, спостерігали тенденцію до підвищення вмісту триацилгліцеролів і неетерифікованих жирних кислот. Крім цього, у крові щурів з ЦД на тлі вірогідного зменшення вмісту фосфоліпідів відбувалося зміщення спектра різних їхніх фрракцій.

ISSN 1996-4536 (print) • ISSN 2311-0783 (on-line) • Біологічні Студії / Studia Biologica • 2018 • Том 12/№3-4 • С. 35-46 
За випоювання розчину хром цитрату у тварин дослідних груп вірогідно знижувався вміст загальних ліпідів, етерифрікованого та неетерифікованого холестеролу, спостерігалася спрямованість до зниження вмісту триацилгліцеролів і неетерифікованих жирних кислот, однак зростав вміст фоссроліпідів. Зміни вмісту окремих класів ліпідів у крові щурів із алоксановим діабетом під впливом добавок хром цитрату мають різноспрямований і дозозалежний характер.

Ключові слова: щури, цитрат хрому, кров, загальні ліпіди, фросфроліпіди

Одержано: 07.12.2018

ISSN 1996-4536 (print) •ISSN 2311-0783 (on-line) • Біологічні Студії / Studia Biologica • 2018 • Том 12/№3-4 • С. 35-46 